\title{
Measurement of Pozzolanic Activity Index of Scoria, Pumice, and Rice Husk Ash as Potential Supplementary Cementitious Materials for Portland Cement
}

\author{
Hieronimi A. Mboya, ${ }^{1,2}$ Cecil K. King'ondu, ${ }^{1,3}$ Karoli N. Njau, ${ }^{1}$ and Alex L. Mrema ${ }^{4}$ \\ ${ }^{1}$ Department of Materials, Energy Science and Engineering, The Nelson Mandela Institution of Science and Technology, \\ P.O. Box 447, Arusha, Tanzania \\ ${ }^{2}$ Department of Built Environment Engineering, Mbeya University of Science and Technology, P.O. Box 131, Mbeya, Tanzania \\ ${ }^{3}$ Department of Chemistry, South Eastern Kenya University, P.O. Box 170-90200, Kitui, Kenya \\ ${ }^{4}$ Department of Structural and Construction Engineering, University of Dar es Salaam, P.O. Box 35131, Dar es Salaam, Tanzania
}

Correspondence should be addressed to Hieronimi A. Mboya; hamboya@gmail.com

Received 31 March 2017; Accepted 5 June 2017; Published 6 August 2017

Academic Editor: Ghassan Chehab

Copyright (C) 2017 Hieronimi A. Mboya et al. This is an open access article distributed under the Creative Commons Attribution License, which permits unrestricted use, distribution, and reproduction in any medium, provided the original work is properly cited.

\begin{abstract}
This work investigated the properties of scoria and pumice as supplementary cementitious materials (SCMs) for Portland cement and compared to those of rice husk ash (RHA). X-ray fluorescence, X-ray diffraction, and pozzolanic activity index (PAI) tests confirmed the suitability of these two materials as potential SCMs. Scoria and RHA samples achieved over $75 \%$ PAI at 7 days whereas pumice did this after 28 days. Initial and final mean setting times observed for the composite cement blended with these materials were 166 and $285 \mathrm{~min}$, respectively. These setting times are longer than that of ordinary Portland cement but shorter compared to that of common Portland pozzolana cement. The ultimate mean compressive strengths achieved at 28 days of curing were 42.5, 44.8, and 43.0 MPa for scoria, pumice, and RHA, respectively, signifying that these materials are good SCMs. Higher fineness yielded higher ultimate mean strength. For instance, a scoria sample with a fineness of $575 \mathrm{~m}^{2} / \mathrm{kg}$ achieved the strength of 52.2 MPa after 28 days.
\end{abstract}

\section{Introduction}

Mortar is a workable paste prepared by adding water to a mixture of sand and binding materials like cement or lime. Cement-sand mortar is used for binding building materials such as clay bricks, concrete blocks, stones, and coarse aggregates in concrete and for plastering. The strength and durability of a mortar or a concrete is a function of the volume and quality of the binder and the water/binder ratio used. Hydration of cement gives the strength of mortar and concrete; the hydration products fill the pores between the aggregates. The addition of supplementary cementitious materials (SCMs) reduces the amount of cement and improves the properties of mortar and concrete such as mechanical strengths, resistance to chemical attack, reduced permeability, and shrinkage $[1,2]$. SCMs are pozzolans with a high amount of silica $\left(\mathrm{SiO}_{2}\right)$ and alumina $\left(\mathrm{Al}_{2} \mathrm{O}_{3}\right)$. As such, they react, in the presence of water, with calcium hydroxide $(\mathrm{CH})$ at ordinary temperature to form calcium silicate hydrates (C-S-H) and calcium aluminosilicate hydrates (C-A-H). Both the $\mathrm{C}-\mathrm{S}-\mathrm{H}$ and $\mathrm{C}-\mathrm{A}-\mathrm{H}$ bind the aggregates and give additional strength to mortar and concrete. Fly ash, silica fume, ground granulated blast furnace slag, diatomaceous earth, and metakaolin are frequently used SCMs. Sugar cane bagasse ash and rice husk ash (RHA) obtained from agricultural byproducts are also used as SCMs. The use of SCMs is driven by reasons of their abundance and economic and environmental benefits and today's advances in cement technology. The influence of SCMs on the properties of blended cement in mortar and concrete such as setting times and early strength depends on the quantity and quality of the reactive $\mathrm{SiO}_{2}$ and $\mathrm{Al}_{2} \mathrm{O}_{3}$ present, particle size distribution (PSD), and the specific surface area. These three dictate the amounts of $\mathrm{CH}$ consumed by SCMs and the degree of C-S-H and C-A-H formation. In contrast, PSD 
TABLE 1: Chemical compositions of scoria, pumice, and RHA from different literatures.

\begin{tabular}{|c|c|c|c|c|c|c|c|c|}
\hline Sample & $\begin{array}{c}\mathrm{SiO}_{2} \\
{[\%]} \\
\end{array}$ & $\begin{array}{c}\mathrm{Fe}_{2} \mathrm{O}_{3} \\
{[\%]}\end{array}$ & $\begin{array}{c}\mathrm{Al}_{2} \mathrm{O}_{3} \\
{[\%]}\end{array}$ & $\begin{array}{r}\mathrm{CaO} \\
{[\%]} \\
\end{array}$ & $\begin{array}{c}\text { Alkali } \\
{[\%]}\end{array}$ & $\begin{array}{c}\mathrm{MgO} \\
{[\%]} \\
\end{array}$ & $\begin{array}{c}\mathrm{TiO}_{2} \\
{[\%]} \\
\end{array}$ & $\begin{array}{c}\text { L.o.I } \\
{[\%]}\end{array}$ \\
\hline \multicolumn{9}{|c|}{ Scoria data from different literature } \\
\hline Khandaker and Hossain [8] & $45-50$ & $7-10$ & $13-15$ & $5-8$ & $4-6$ & $4-6$ & & $1.25-1.5$ \\
\hline Taha et al. [15], Yemen scoria & $47-50$ & \multicolumn{2}{|c|}{$28-30$} & $7-10$ & $3-6$ & & & \\
\hline Taha et al. [15], Italy scoria & 51.4 & \multicolumn{2}{|c|}{25.7} & 6.5 & 6.4 & & & \\
\hline Njau et al. [16] & 35.4 & \multicolumn{2}{|c|}{31.9} & 12.7 & 5.6 & & & \\
\hline \multicolumn{9}{|c|}{ Pumice data from literature } \\
\hline Ismail et al. [17] & 70.97 & 1.88 & 14.24 & 1.37 & 8.48 & 0.35 & 0.14 & 2.41 \\
\hline \multicolumn{9}{|c|}{ RHA data from different literature } \\
\hline Wansom et al. [6] & 93.59 & 0.31 & 0.89 & 2.28 & 1.30 & & 0.61 & \\
\hline Della et al. [12] (at $\left.700^{\circ} \mathrm{C}\right)$ & 94.95 & 0.26 & 0.39 & 0.54 & 1.19 & 0.9 & 0.2 & 0.85 \\
\hline
\end{tabular}

and specific surface area influence the water/binder ratio, rheology of mortar and concrete, and the rate at which $\mathrm{C}$ $\mathrm{S}-\mathrm{H}$ and $\mathrm{C}-\mathrm{A}-\mathrm{H}$ are formed [3]. The quality of SCMs is evaluated by pozzolanic activity index (PAI) and strength activity index (SAI), which measure the reaction between the amorphous part of pozzolana and calcium hydroxide. A number of methods, categorized as direct and indirect, have been developed for the qualitative and quantitative determination of these indices. Direct and indirect methods measure the amount of $\mathrm{CH}$ consumed and the relative compressive strength, respectively [4]. The direct methods involve chemical titration, electrical conductivity measurement, and thermogravimetric analysis and so forth [3]. The indirect method compares the relative compressive strength of pozzolan blended cement mortar to that of Portland cement mortar. The reliability of each method is an important factor. For instance, Luxán et al's method (direct method) is accurate for early age determination of PAI but McCarter and Tran's method (also a direct method) is more accurate for the later ages [5]. Both of these methods are based on conductivity [6]. Luxán et al. [4] studied PAI of natural rock pozzolan by monitoring the change in conductivity during the first 2 min of a reaction between $5 \mathrm{~g}$ of pozzolan and $200 \mathrm{~mL}$ of saturated $\mathrm{Ca}(\mathrm{OH})_{2}$ solution at $40 \pm 1^{\circ} \mathrm{C} .2 \mathrm{~min}$ were found sufficient for the stabilization of the reaction. Also, McCarter and Tran [5] measured conductivity of various pozzolans mixed with $\mathrm{Ca}(\mathrm{OH})_{2}$ powder and water for $48 \mathrm{~h}$. Stiffening of the paste was observed between 24 and $48 \mathrm{~h}$. On the other hand, Wansom et al. [6] studied and compared various electrical methods of measuring PAI of RHA for $1 \mathrm{~h}$ in a saturated $\mathrm{Ca}(\mathrm{OH})_{2}$-pozzolan-water system. Paya et al. [7] modified Luxán et al's method by using $800 \mathrm{mg}$ of $\mathrm{Ca}(\mathrm{OH})_{2}$ powder in $1000 \mathrm{~mL}$ of deionized water instead of the saturated solution of $\mathrm{Ca}(\mathrm{OH})_{2}$. In their study, the proposed observation time was $120 \mathrm{~min}$ but the actual time used was $\sim 17 \mathrm{~min}$. The above studies limited the time for PAI determination to $48 \mathrm{~h}$. In this study, the time was prolonged to 28 days to reflect the required curing period of cement to achieve ultimate compressive strength. Furthermore, time for taking the readings was tailored to 2,7 , and 28 days to match the curing period for measuring compressive strength of cement-sand mortar. This work aimed at exploring new
SCMs (scoria and pumice), comparing their pozzolanic activity index and performance in the mortar with those made with RHA.

Scoria and pumice are pyroclastic ejecta which is found in many areas around the world [8]. Scoria is composed of red colored fragments indicating the presence of iron. It is highly vesicular and composed of crystalline structure. Pumice is an extrusive volcanic rock material, produced when lava, which is full of water and gases, is ejected on the earth surface by volcanic action [9]. It is light-colored and extremely vesicular and composed of high silica and alumina and low in iron and magnesium. The chemical compositions of scoria and pumice from different sources vary depending on the mineralogical composition, formation temperature, and rate of cooling. The chemical composition of scoria and pumice is shown in Table 1. Although scoria and pumice have pozzolanic properties, they have not yet been used as SCMs to the best of our knowledge.

Rice husk ash is produced when rice husk is incinerated at low temperature $\left(<800^{\circ} \mathrm{C}\right)$ with a controlled supply of air to achieve the reactive silica phase [6]. When incinerated above $800^{\circ} \mathrm{C}$, amorphous silica converts into crystalline silica phase. The properties of the ash depend on chemical composition, purity, fineness, and the amount of amorphous silica which decreases with calcination $[10,11]$. According to Della et al. [12], RHA burned at $700^{\circ} \mathrm{C}$ has $94.95 \%$ of reactive silica (Table 1). Wansom et al. [6] and Givi et al. [13] state that burning of RHA at different temperatures and supply of oxygen results in different amounts of reactive silica.

\section{Materials and Methods}

2.1. Materials. This study was carried out using scoria obtained from Uchira, Kilimanjaro, Tanzania, and pumice and rice husk from Mbeya, Tanzania. Analytical grade calcium hydroxide $\left(\mathrm{Ca}(\mathrm{OH})_{2}\right)$ and Portland Limestone Cement (PLC) CEM II/A-L class $42.5 \mathrm{~N}$ conforming to BS 197-1 were used. Standard sand prepared according to SS- EN 196-1 was also used.

2.2. Experimental Procedures. Samples of scoria, pumice, and rice husk were calcined at different temperatures ranging 
TABLE 2: Sample designation and notation.

\begin{tabular}{lccc}
\hline $\begin{array}{l}\text { Calcination temperature } \\
\left({ }^{\circ} \mathrm{C}\right)\end{array}$ & \multicolumn{2}{c}{ Sample designation } \\
\hline 900 & Scoria & Pumice & Rice husk ash (RHA) \\
800 & S 900 & P 900 & RHA 900 \\
700 & S 800 & P 800 & RHA 800 \\
600 & S 700 & P 700 & RHA 700 \\
Uncontrolled condition & S 600 & P 600 & RHA 600 \\
Natural & & & RHA-uc \\
\hline
\end{tabular}

* Natural scoria and pumice; ${ }^{*}$ combustion in an uncontrolled condition.

from 600 to $900^{\circ} \mathrm{C}$ in a muffle furnace at a rate of $7^{\circ} \mathrm{C} / \mathrm{min}$. They were kept at the respective temperature for $1 \mathrm{~h}$ and then cooled to room temperature. Natural samples of scoria and pumice and a sample of rice husk ash incinerated in uncontrolled condition were included in this study for comparison purposes. The incineration in uncontrolled condition was set in a small room of $2 \mathrm{~m}^{2}$ and the rice husks were sprayed to $0.5 \mathrm{~m}$ depth. The ash obtained from this condition was designated as RHA-uc. All samples were milled using disc mill model 4A100L6T1 SN 535277 at a rate of $2 \mathrm{~kg} / \mathrm{h}$ and sieved through $75 \mu \mathrm{BS}$ standard sieve mounted on automatic sieve shaker [14]. 95\% of the weight of each sample passed this sieve. The samples designations and notation are shown in Table 2.

2.2.1. Determination of Chemical and Phase Composition. Chemical and phase compositions of the samples in Table 2 were analyzed by X-ray fluorescence (XRF) and X-ray diffraction (XRD) techniques $[18,19]$. XRF analysis was performed using Bruker XRF-S8 Tiger spectrometer, while XRD analysis was done using Bruker S8 diffractometer with $\mathrm{Cu} \mathrm{K}_{\alpha}$ radiation. Scanning was performed within $2^{\circ} \leq 2$ theta $\leq 60^{\circ}$ for the XRF samples and $5^{\circ} \leq 2$ theta $\leq 70^{\circ}$ for the XRD samples. The scanning rate for both XRF and XRD was 0.02 degrees/sec. The analyses were done according to ASTM C 618 [20] which requires the sum of the basic oxides, silica, alumina, and ferrous, to be higher than $70 \%$ for pozzolana.

2.2.2. Determination of Specific Gravity, Specific Surface Area, Particle Size Distribution (PSD), and Pozzolanic Activity Index $(P A I)$. The specific gravity (SG) of cement and powder materials was determined according to SS-EN 197-1, ASTM D 854, and B8E1-1 [21-23]. Specific surface area was measured using Automatic Blaine Apparatus (AIM-391-3) SN 2001 from Aimil Ltd., India [24]. Particle size distribution (PSD) was analyzed using isopropanol procedure and Laser Mastersizer $[23,25]$. Pozzolanic activity index was measured using $200 \mathrm{mg}$ of $\mathrm{Ca}(\mathrm{OH})_{2}$ in $250 \mathrm{~mL}$ distilled water [4, 7].

2.2.3. Determination of Setting Time and Soundness. Setting times and soundness were determined according to SSEN 196-3 [19] from standard consistency paste prepared by replacing cement with $10,20,30$, and $40 \%$ of scoria, pumice, or RHA treated at different temperatures (Table 2). In principle, standard consistency paste is the one having water/cement ratio between 26 and 33\% [26]. Initial setting time of cement should not be less than 30 min. SS-EN 197-1 [21], however, specifies an initial setting time of $60 \mathrm{~min}$ and a final setting time of no more than $10 \mathrm{~h}$ for cement strength class 42.5 . There is no limit which is given for the final setting time. Neville and Brooks, [26] suggested $90 \mathrm{~min}+1.2$ times the initial setting time as the final setting time.

2.2.4. Determination of Compressive Strength. The compressive strength of cement mortar made of PLC blended with 10, 20,30 , and $40 \%$ of scoria, pumice, or RHA treated at different temperatures was measured according to SS-EN 196-1 [27]. Normally, this test uses cement mortar prism of $40 \times 40 \times$ $160 \mathrm{~mm}$ or $70.7 \mathrm{~mm}$ cubes. Compression test of cement mortar is also measured on cubes of $50 \mathrm{~mm}$ with cement/sand ratio $1: 2.75$ and water/cement ratio $0.485[26,28,29]$. In this research, SS-EN 196-1 [27] was adopted using $40 \mathrm{~mm}$ cubes. Three test and reference cubes were cast and crushed at curing periods of $2,7,28,56$, and 90 days using compression machines conforming to SS-EN 196-1 [27]. The loading rate was adjusted to a range between 12 and $24 \mathrm{kN} / \mathrm{min}$. The results are as shown in Figures 8 and 10.

\section{Results and Discussion}

3.1. Materials Chemical Composition and Physical Properties. Table 3 shows results for the chemical composition of scoria, pumice, and RHA materials treated at different temperatures. The mean value for silica $\left(\mathrm{SiO}_{2}\right)$ content was found to be 42.9 , 57.5, and 92.7\%; basic oxide 71.1, 78.4, and 93.3\%; calcium oxide (CaO) 10.1, 1.1, and 0.66\%; alkali 3.2, 9.1, and 1.6\%; and loss on ignition $5.2,7.4$, and $1.9 \%$ for scoria, pumice, and RHA samples, respectively. Scoria, pumice, and RHA samples indicated significant difference with the degree of marginal difference $P<0.05$ for the basic oxides and loss on ignition. Observation on the chemical composition revealed that significant influence was caused more by the type of materials than the calcination temperature. Scoria samples showed high $\mathrm{CaO}$ content indicating high latent hydraulic properties. Pumice, on the other hand, had low calcium content with low hydraulic properties. The chemical compositions of scoria and pumice were comparable with those reported in the literature (Table 1). The sum of the basic oxides observed was over $70 \%$ as required by ASTM C 618 [20] for a material to qualify as a pozzolan.

Table 3 shows the specific gravity (SG) and specific surface area of scoria, pumice, and RHA. The specific gravity increased with calcination temperature for both the pumice and RHA samples. The natural pumice sample (P-N) showed an SG of 2.39. Upon calcination at $900^{\circ} \mathrm{C}$, the specific gravity increased to 2.50. Similarly, SG increased from 2.17 for RHA-uc sample to 2.28 for RHA sample calcined at $900^{\circ} \mathrm{C}$ (RHA 900) (Table 3). There was no obvious trend between specific gravity and calcination temperature observed for the scoria samples. The increase in specific gravity with temperature for pumice and RHA samples was probably due to the reduction of porosity and increased crystallinity as the materials sintered at higher temperatures. Similarly, specific surface area of scoria and RHA decreased with calcination 


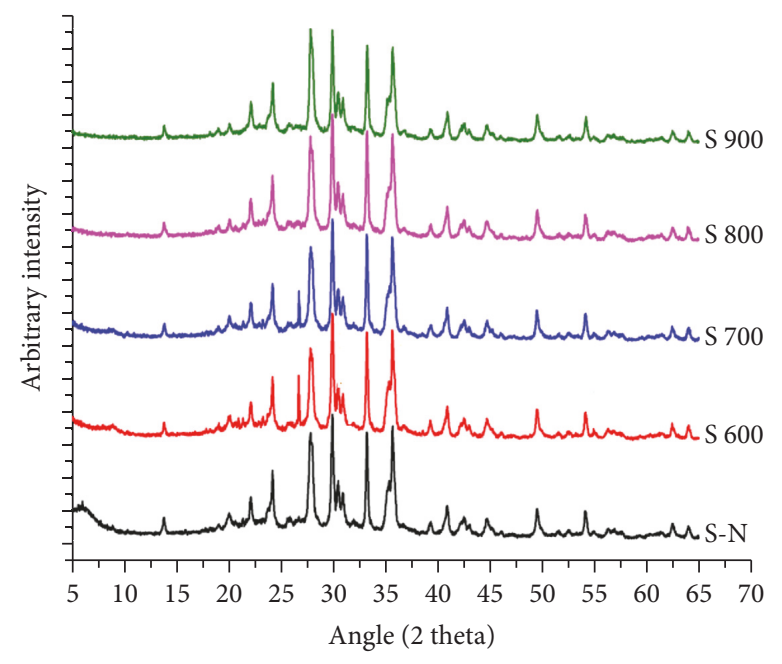

(a)

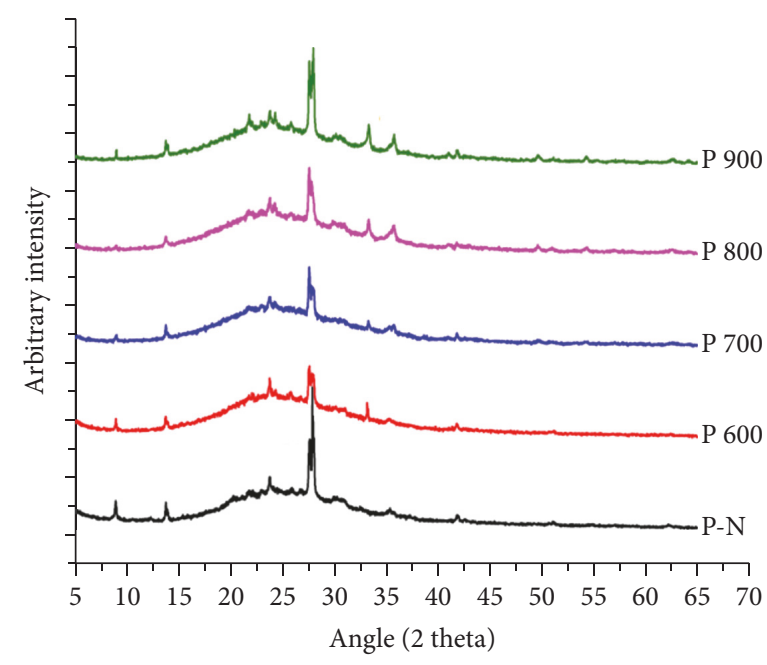

(b)

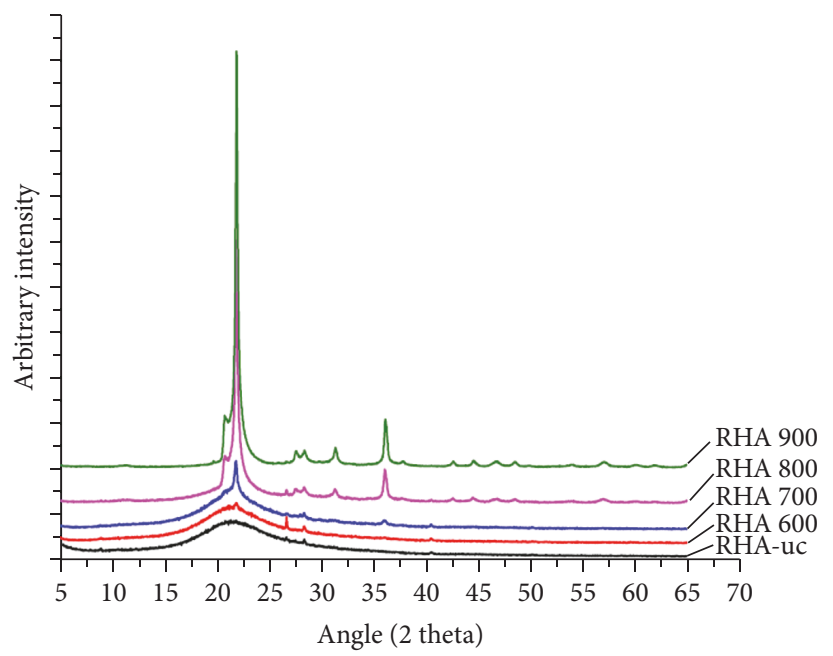

(c)

FIGURE 1: XRD patterns for (a) scoria, (b) pumice, and (c) RHA.

temperatures from 575 (for S-N) to $325 \mathrm{~m}^{2} / \mathrm{kg}$ (for S 900) and from 611 (for RHA-uc) to $282 \mathrm{~m}^{2} / \mathrm{kg}$ (for RHA 900), respectively. This was probably due to the strengthening of the microstructure via neck growth and agglomeration, densification, and coarsening of the microstructure, which occurred as the materials sintered at elevated temperatures. The low specific gravities of scoria, pumice, and RHA as compared to Portland cement (3.15) are attributed to the porous microstructure. No obvious trend between surface area and calcination temperature was observed for pumice samples.

Figure 1 shows the XRD pattern of materials at different calcination temperatures. Figure 1(a) shows multiple sharp peaks indicative of polycrystalline nature of scoria. There was no observable change in crystallinity of scoria with calcination temperature as peak intensities and widths remained almost the same except for a peak around $6^{\circ} 2$ theta which disappeared at higher temperatures. The main phases observed were pyroxene (augite/diopside) and hematite. Similar to scoria materials, no changes in crystallinity with calcination temperature were observed for pumice samples (Figure 1(b)). The peak at $33^{\circ} 2$ theta for P $600-900$ could be due to preferred orientation. The main phases observed were feldspar (anorthoclase/anorthite) and mica. On the contrary, RHA samples showed dramatic changes in peak intensities and widths with calcination temperature (Figure 1(c)). The XRD pattern for RHA-uc and RHA 600 showed one broad peak at around $22^{\circ} 2$ theta attributed to amorphous silica [11, 30]. This peak becomes narrow and intense at temperatures beyond $600^{\circ} \mathrm{C}$. At $800-900^{\circ} \mathrm{C}$, more sharp peaks evolved correspondingly to crystalline phase (cristobalite).

3.2. Particle Size Distribution (PSD). Figure 2 shows the PSD profiles of scoria, pumice, and RHA. The PSD profiles indicated well-graded particles where all particles, from coarse to fine, were present. Fine particles are more reactive and have good parking effect. The specific surface area and PSD not only are critical to pozzolanic reactions but also translate to reduced setting times and enhanced final strength and packing density of mortar and concrete. This 
TABLE 3: Temperature effects on chemical composition and physical properties of the materials used.

\begin{tabular}{|c|c|c|c|c|c|c|c|c|c|c|}
\hline Sample & $\begin{array}{c}\mathrm{SiO}_{2} \\
{[\%]} \\
\end{array}$ & $\begin{array}{c}\mathrm{Fe}_{2} \mathrm{O}_{3} \\
{[\%]} \\
\end{array}$ & $\begin{array}{c}\mathrm{Al}_{2} \mathrm{O}_{3} \\
{[\%]} \\
\end{array}$ & $\begin{array}{c}\text { Basic oxide } \\
{[\%]} \\
\end{array}$ & $\begin{array}{l}\mathrm{CaO} \\
{[\%]} \\
\end{array}$ & $\begin{array}{c}\text { Alkali } \\
{[\%]}\end{array}$ & $\begin{array}{c}\mathrm{MgO} \\
{[\%]} \\
\end{array}$ & $\begin{array}{c}\text { L.o.I } \\
{[\%]} \\
\end{array}$ & Specific gravity & $\begin{array}{l}\text { Specific surface area } \\
\mathrm{m}^{2} / \mathrm{kg}\end{array}$ \\
\hline S 900 & 41.6 & 15.1 & 13.4 & 70.1 & 10.1 & 4.2 & 5.43 & 5.01 & 2.95 & 325 \\
\hline S 800 & 43.4 & 14.8 & 15.6 & 73.8 & 10.5 & 3.64 & 5.43 & 1.47 & 2.96 & 314 \\
\hline S 700 & 45.3 & 14.6 & 12.9 & 72.8 & 10.2 & 3.16 & 5.46 & 3.52 & 2.97 & 333 \\
\hline S 600 & 44.5 & 15.2 & 12 & 71.7 & 10.3 & 3.3 & 5.04 & 5.05 & 3.04 & 456 \\
\hline S-N & 40.0 & 13.9 & 13 & 66.9 & 9.6 & 3.15 & 4.62 & 10.76 & 2.93 & 575 \\
\hline P 900 & 63.1 & 4.48 & 15.9 & 83.48 & 0.62 & 10.25 & 0.27 & 4.18 & 2.50 & 369 \\
\hline P 800 & 57.3 & 4.56 & 16.6 & 78.46 & 1.24 & 11.23 & 0.26 & 7.45 & 2.41 & 479 \\
\hline P 700 & 55.0 & 4.42 & 15.6 & 75.02 & 0.8 & 10.82 & 0.24 & 10.32 & 2.43 & 447 \\
\hline P 600 & 56.6 & 4.56 & 17.5 & 78.66 & 1.27 & 11.7 & 0.31 & 6.2 & 2.43 & 573 \\
\hline $\mathrm{P}-\mathrm{N}$ & 55.4 & 4.64 & 16.4 & 76.44 & 1.7 & 10.79 & 0.62 & 8.78 & 2.39 & 506 \\
\hline RHA 900 & 88.8 & 0.44 & 0.32 & 89.56 & 0.65 & 2.02 & 0.24 & 6.07 & 2.28 & 282 \\
\hline RHA 800 & 92.4 & 0.49 & 0.38 & 93.27 & 0.8 & 2.42 & 0.3 & 2.13 & 2.21 & 300 \\
\hline RHA 700 & 94.7 & 0.24 & 0.29 & 95.23 & 0.55 & 2.35 & 0.35 & 0.21 & 2.15 & 309 \\
\hline RHA 600 & 94.25 & 0.26 & 0.33 & 94.84 & 0.63 & 2.51 & 0.28 & 0.56 & 2.14 & 462 \\
\hline RHA-uc & 93.5 & 0.53 & 0 & 94.03 & 0.67 & 2.65 & 0.38 & 0.86 & 2.17 & 611 \\
\hline
\end{tabular}
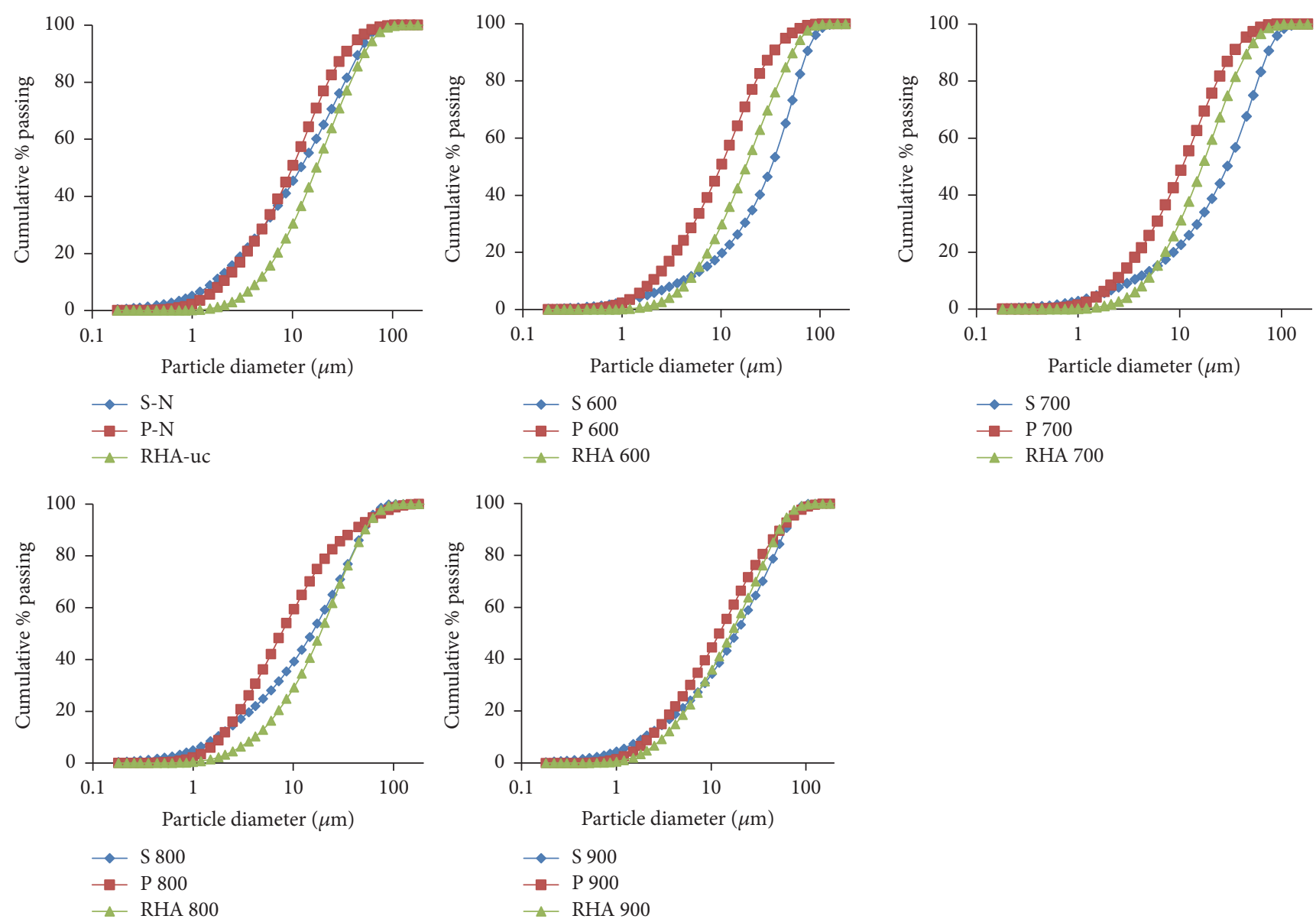

FIGURE 2: PSD profiles for scoria, pumice, and RHA at different calcination temperatures.

also implies reduced cracking, shrinkage, permeability, and chemical attack of a mortar or concrete.

3.3. Pozzolanic Activity Index (PAI). Figure 3 shows pozzolanic activity index (PAI) patterns of scoria, pumice, and
RHA. Pozzolanic activity index increased rapidly within the first $48 \mathrm{~h}$ after which the rate decreased and stabilized for scoria and RHA samples (Figures 3(a) and 3(c)). This was indicative of rapid depletion of the calcium ions $\left(\mathrm{Ca}^{2+}\right)$ associated with pozzolanic reactions. As the concentrations 


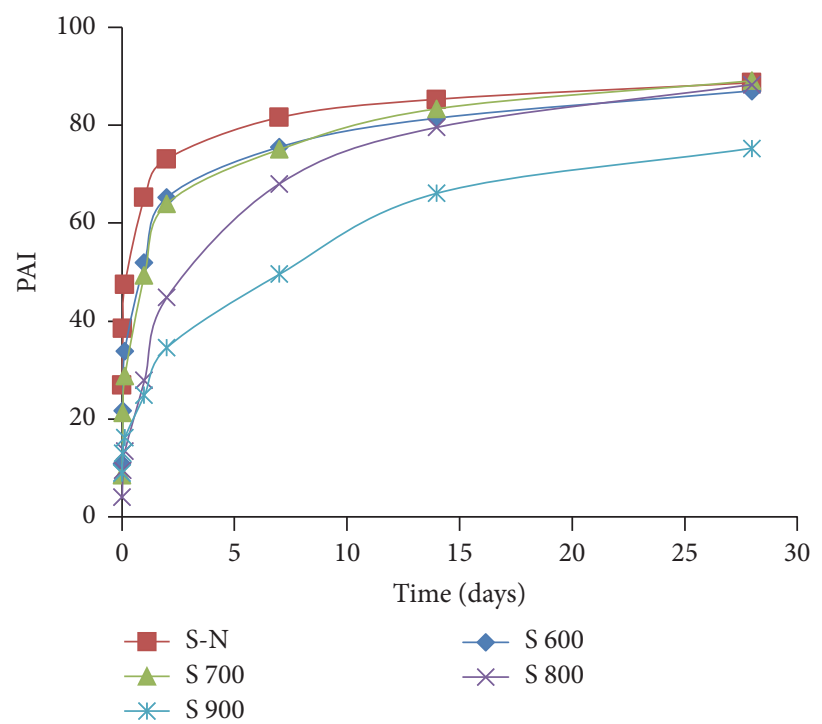

(a)

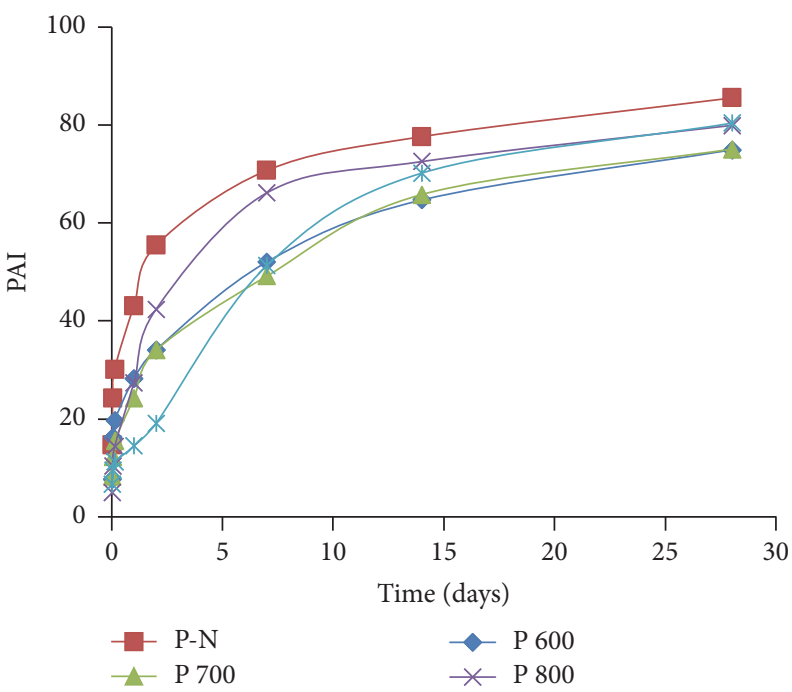

(b)

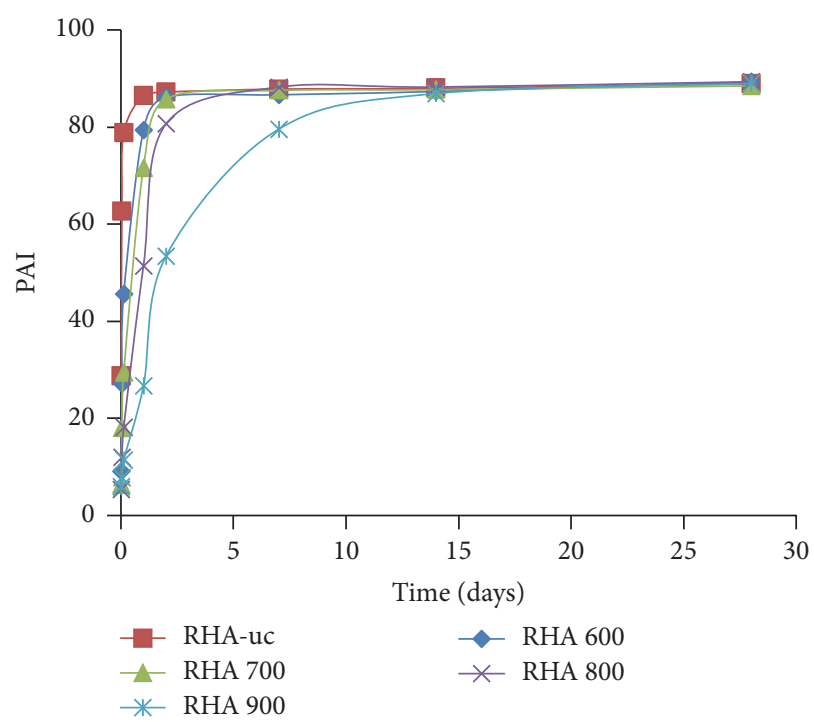

(c)

Figure 3: PAI versus reaction time: (a) scoria, (b) pumice, and (c) RHA.

of $\mathrm{Ca}^{2+}$ ions reduced with time, the rates of PAI decreased and stabilized when all the $\mathrm{Ca}^{2+}$ ions were consumed. High PAI of RHA samples correlates well with the XRF and the XRD results in Table 3 and Figure 1(c) which show high amorphous silica content in RHA samples compared to scoria and pumice. Calcination temperature and hence the degree of crystallinity were found to have a strong influence on PAI. This was attributed to the fact that, at low temperatures, less crystalline silica is obtained, which is more reactive than the highly crystalline silica obtained at high temperatures. The increase in the degree of crystallinity with temperature is clearly exhibited by XRD patterns in Figure 1(c), which show an evolution of narrow and intense peaks with the increase in temperature. The RHA-uc and RHA 600 and 700 samples were rather amorphous compared to their scoria and pumice counterparts (Figures 1(a) and 1(b)). This explains why the
PAI of RHA-uc, RHA 600, and RHA 700 samples were higher at 88,86 , and $87 \%$ compared to 82,75 , and 75 and 70,52 , and $49 \%$ for S-N, S 600, and S 700 and P-N, P 600, and $\mathrm{P} 700$, respectively, at 7 days. In contrast, pumice attained 86,75 , and $75 \%$ for P-N, P 600 , and P 700 at 28 days. The failures of pumice samples to achieve the minimum PAI of 75\% stipulated by ASTM C 618 within 7 days indicated their inability to attain sufficient strength within 7 days. The PAI results show, however, that composite cement made of these materials would achieve the ultimate compressive strength within 28 days.

3.4. Setting Times. Prior to setting times and soundness tests, standard consistency paste was prepared from cement blended with scoria, pumice, or RHA at $10,20,30$, and $40 \%$ replacement levels. The standard consistency paste indicated 
TABLE 4: The influence of materials, temperature, and chemical composition on initial setting times, final setting times, shrinkage, and soundness.

\begin{tabular}{lccccc}
\hline Independent variable & Pillai trace & Approx. F & Num DF & Den DF & \multicolumn{2}{c}{$P$ value } \\
\hline Materials & 0.33431 & 6.4029 & 4 & 51 & 51 \\
Temperature & 0.13917 & 2.0613 & 4 & 51 & 0.0996102 \\
Fineness & 0.26691 & 4.6422 & 4 & 51 & $0.0028440^{* * *}$ \\
Basic oxides & 0.13841 & 2.0483 & 4 & 51 & 0.1014302 \\
Replacement & 0.11097 & 1.5915 & 4 & 0.1907633 \\
\hline
\end{tabular}

${ }^{* *} P<0.01,{ }^{* * *} P<0.001$.

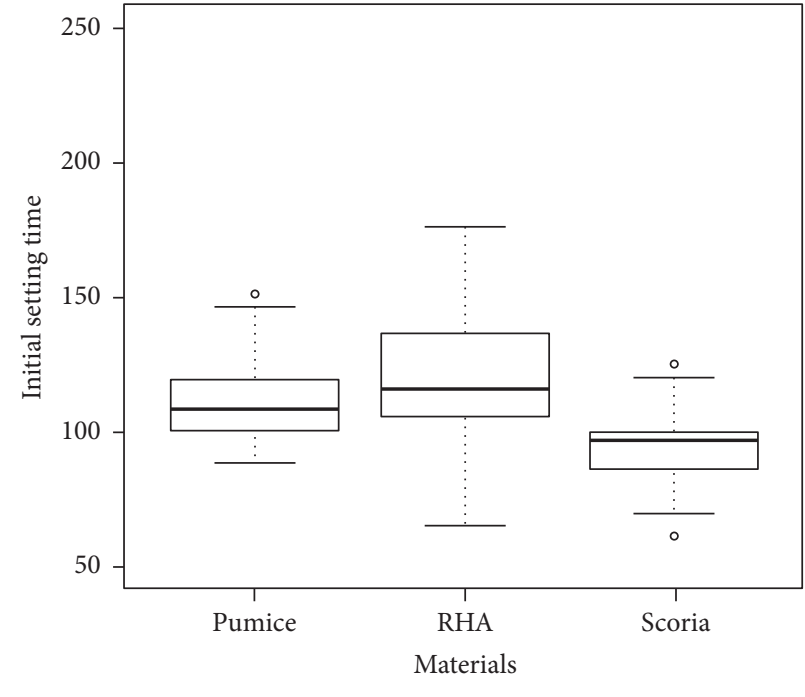

- Outliers/extreme values

(a)

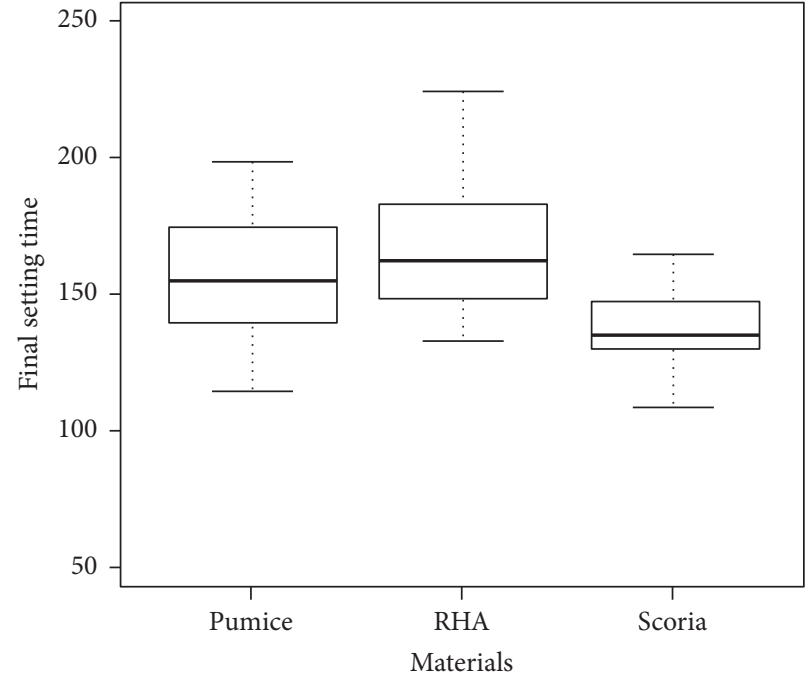

(b)

FIGURE 4: Influence of materials on setting times: (a) initial setting time and (b) final setting time.

water-cement ratio requirement of between 0.26 and 0.33 except for RHA-uc, RHA 600, and RHA 700, which showed water-cement ratio of 0.38 at $40 \%$ replacement level. Table 4 shows the influence of materials and fineness on setting times of blended cement. The analysis of experimental data indicated that materials and fineness affected the setting times significantly. The level of marginal significance observed for the initial setting time and final setting times was $P<0.05$ for fineness and materials, correspondingly (Table 4, Figures 4 and 5). The difference was due to variation in mineralogy, chemical composition, and fineness, which dictate the rate and type of chemical reactions to take place. Natural scoria (S-N) was found to be very reactive; as such, it gave the least mean initial setting time of $80 \mathrm{~min}$ (Figure 5(a)). This was attributed to the low crystallinity and high fineness of $575 \mathrm{~m}^{2} / \mathrm{kg}$. Nevertheless, natural pumice (P-N) reacted slowly despite its high fineness of $506 \mathrm{~m}^{2} / \mathrm{kg}$ because of delayed pozzolanic reaction. Although RHA 600 was amorphous and had a fineness of $462 \mathrm{~m}^{2} / \mathrm{kg}$, it showed significantly delayed setting times (154 min initial setting time and $190 \mathrm{~min}$ final setting time) owing to the high water content (Figure 5(c)). The highest mean initial setting times observed were 103, 146, and 154 min for S 800, P 900, and RHA 600, respectively. Likewise, the highest final setting times (FST) were 156, 182, and
190 min for S 900, P 900, and RHA 600, respectively (Figures 4 and 5). Initial and final mean setting times observed were shorter compared to those of Portland pozzolana cement, which were 166 and $285 \mathrm{~min}$, respectively.

3.5. Shrinkage and Soundness. Figures 6 and 7 show shrinkage and soundness test results. The statistical analysis indicated that the type of material and fineness had a major influence on soundness and shrinkage. Marginal significance for the type of material and fineness $P<0.05$ (Table 4) was observed between pumice-RHA and pumice-scoria (Figure 6) correspondingly. The maximum values observed for the materials were 2 and $1.5 \mathrm{~mm}$ for shrinkage and soundness, respectively. The minimum and maximum mean values for shrinkage and soundness observed were 0.5 and $1.0 \mathrm{~mm}$, respectively. These results imply that $\mathrm{MgO}$ and alkali had no effect on the blended cement and hence the $\mathrm{MgO}$ and alkali contents in our SCMs are within the acceptable levels. The values obtained for soundness and shrinkage in our study are acceptable according to SS-EN 196-3 [19].

3.6. Compressive Strength of Scoria and Pumice Blended Cement. Table 5 shows statistical analysis of compressive strength test results of scoria, pumice, and RHA blended 

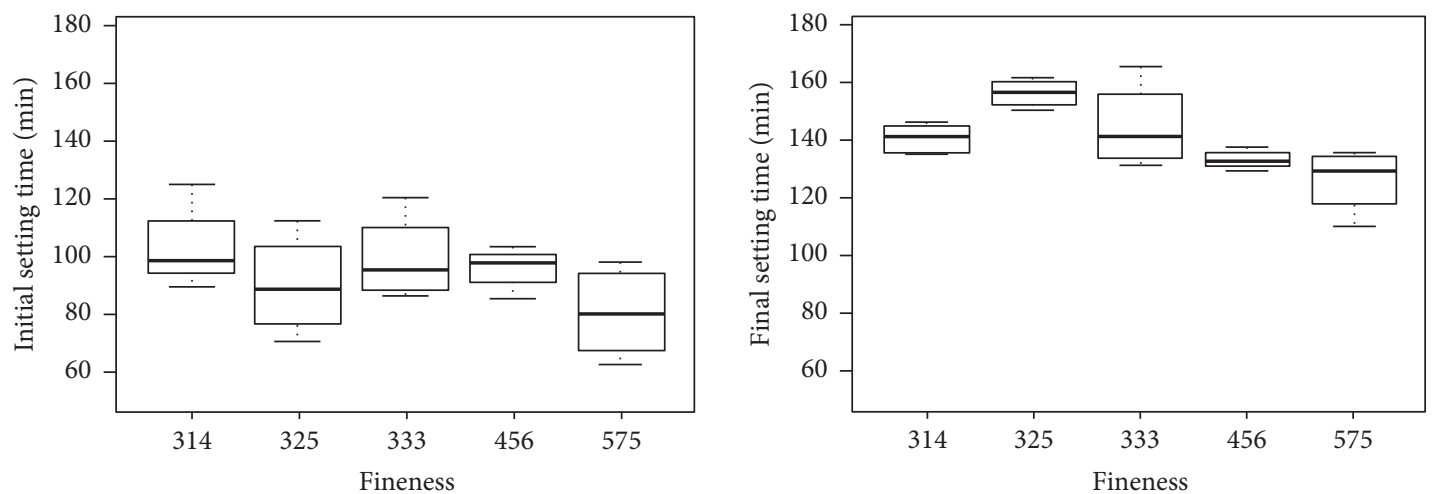

(a)
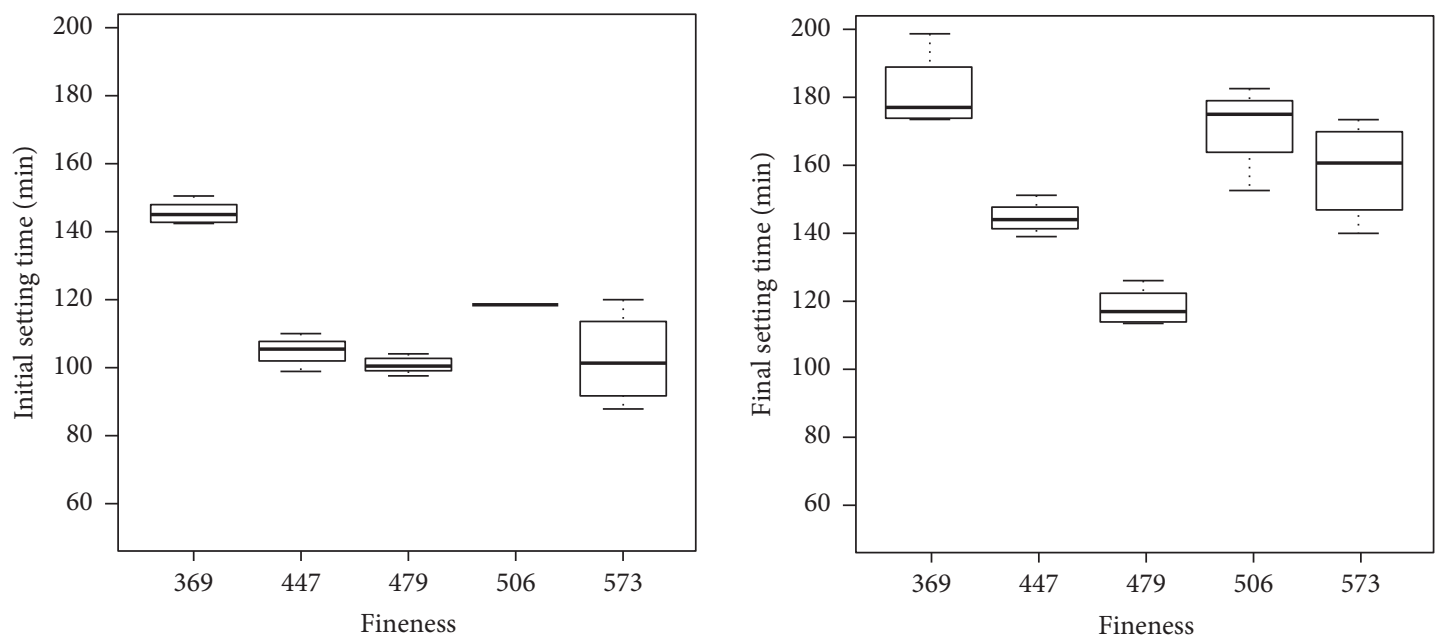

(b)
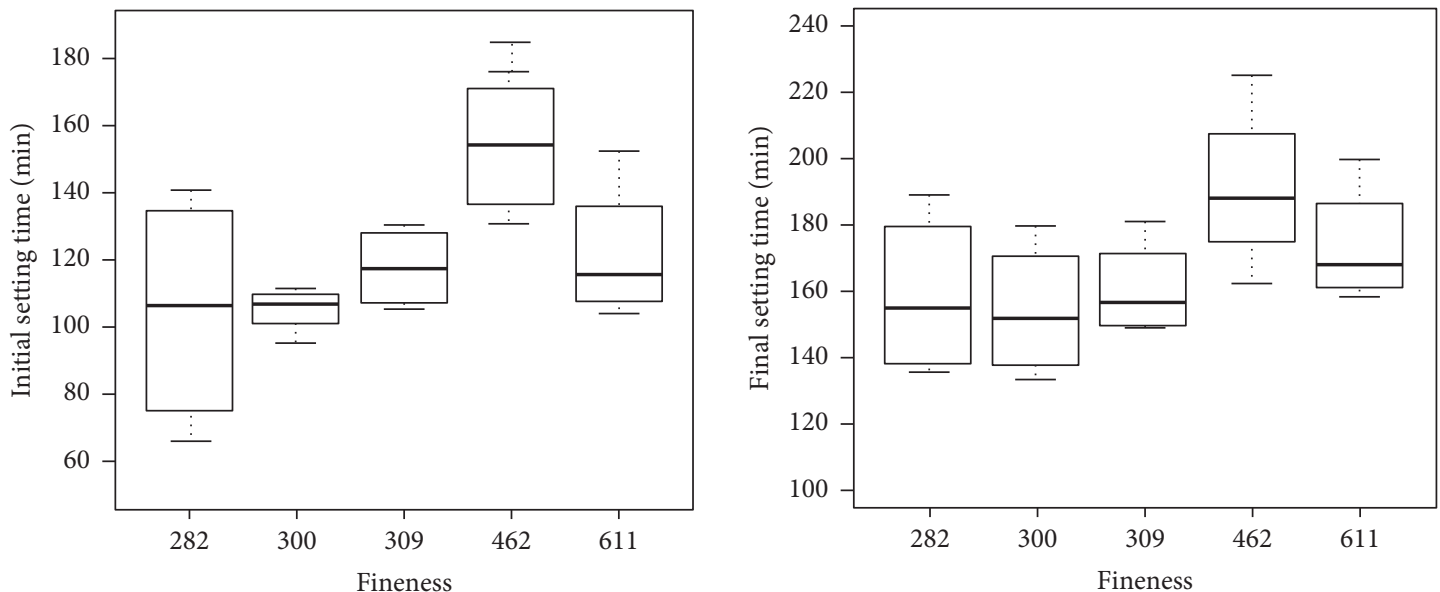

(c)

FIGURE 5: Influence of fineness on setting times: (a) scoria, (b) pumice, and (c) rice husk ash.

TABLE 5: Factors influencing compressive strength (MPa).

\begin{tabular}{lccccc}
\hline Independent variable & Pillai trace & Approx. $F$ & Num DF & Den DF & \multicolumn{2}{c}{$P$ value } \\
\hline Materials & 0.29584 & 4.2854 & 5 & 51 & $0.002492^{* *}$ \\
Temperature & 0.18776 & 2.3579 & 5 & 51 & $0.053215^{\text {ns }}$ \\
Fineness & 0.28073 & 3.9811 & 5 & 51 & $0.003997^{* *}$ \\
Replacement & 0.58722 & 14.5108 & 5 & 51 & $7.733 e-09^{* * *}$ \\
\hline
\end{tabular}

${ }^{* *} P<0.01,{ }^{* * *} P<0.001$, and ns = nonsignificant $(P>0.05)$. 


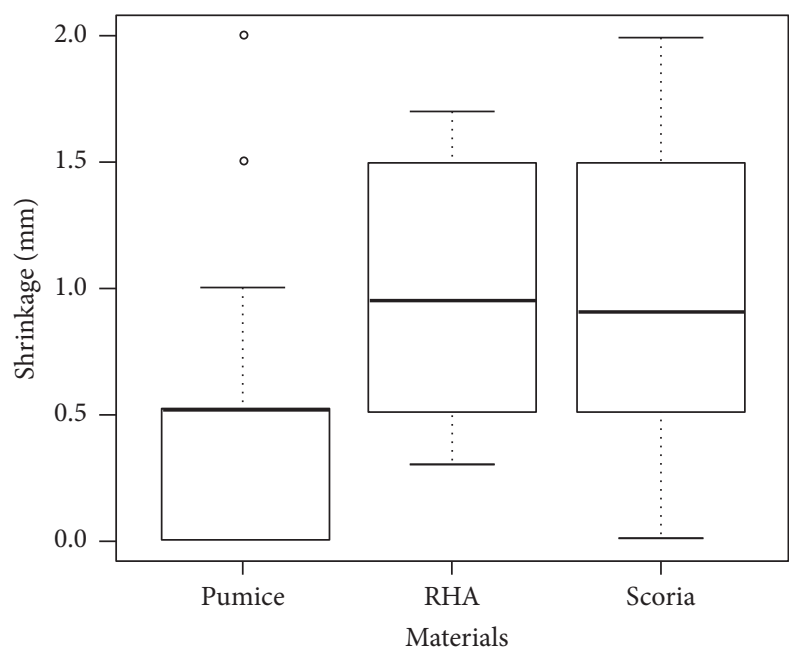

- Outliers/extreme values

(a)

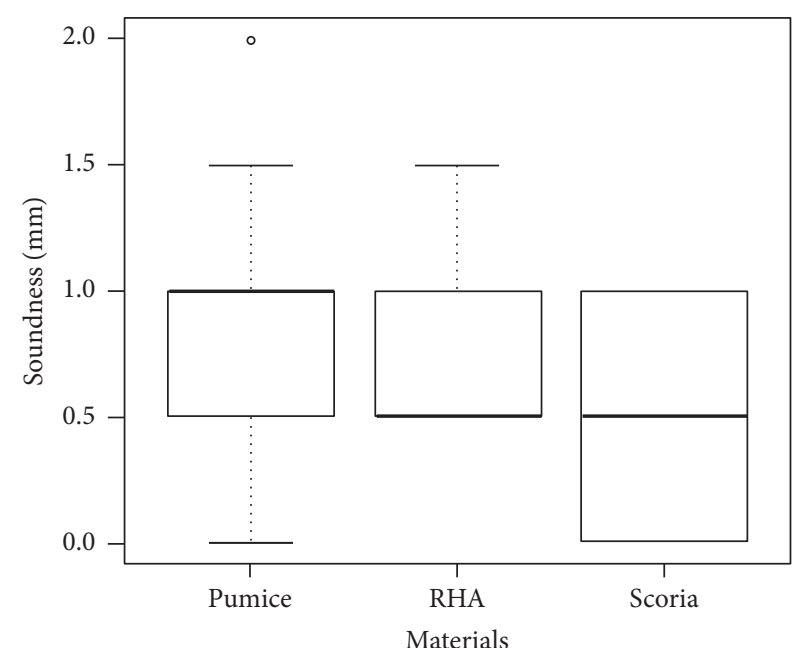

- Outliers/extreme values

(b)

FIGURE 6: Effect of materials on (a) shrinkage and (b) soundness.

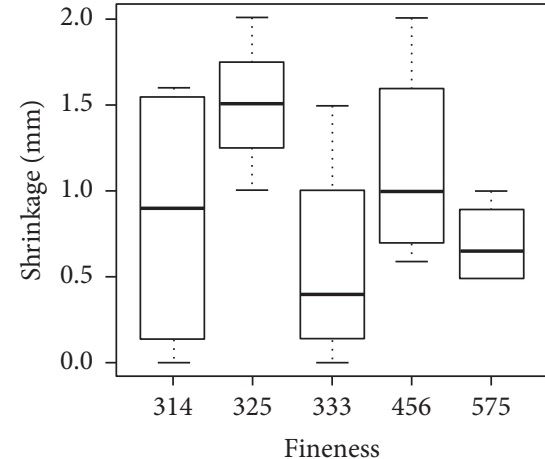

(i) Scoria

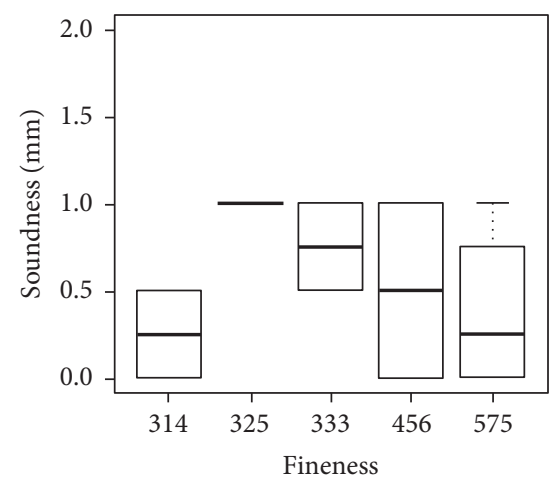

(i) Scoria

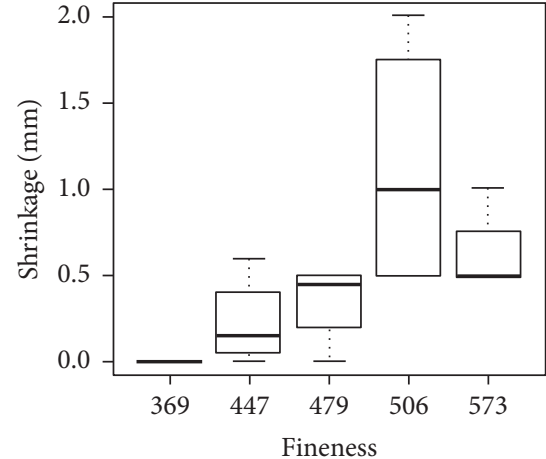

(ii) Pumice

(a)

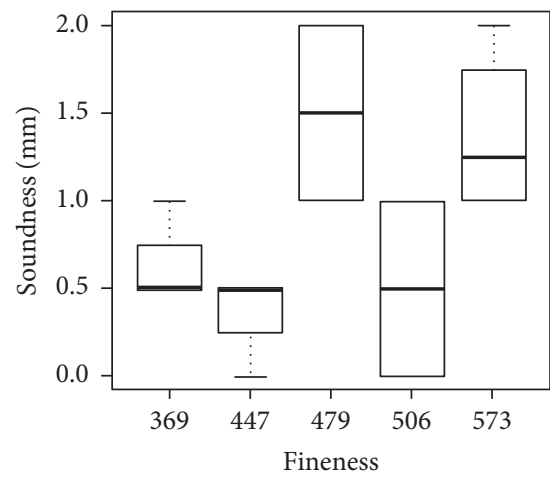

(ii) Pumice

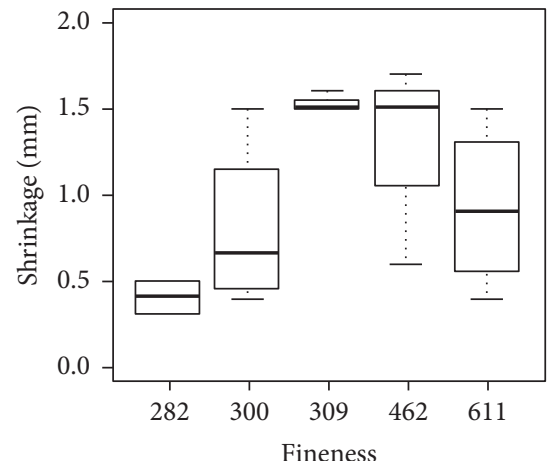

(iii) Rice husk ash

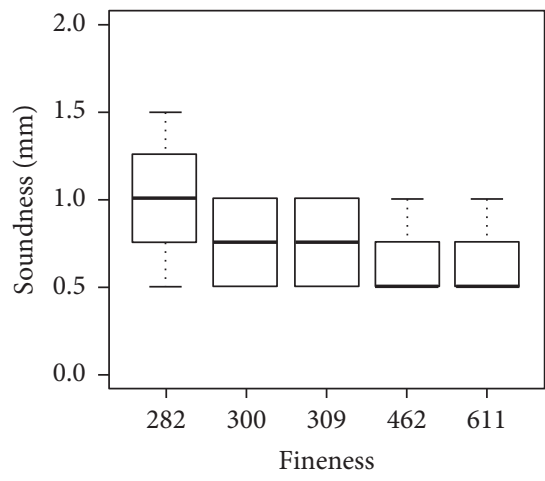

(iii) Rice husk ash

(b)

FIGURE 7: Effect of fineness on (a) shrinkage and (b) soundness.

cement. The level of cement replacement, fineness, and type of material was found to have a huge influence on the compressive strength development. The level of marginal significance observed for the level of cement replacement, fineness, and type of materials was $P<0.05$. Compressive strengths of all samples increased with curing age but decreased with the percent of cement replaced (Figure 8). Compressive strength increased fast up to 28 days beyond 

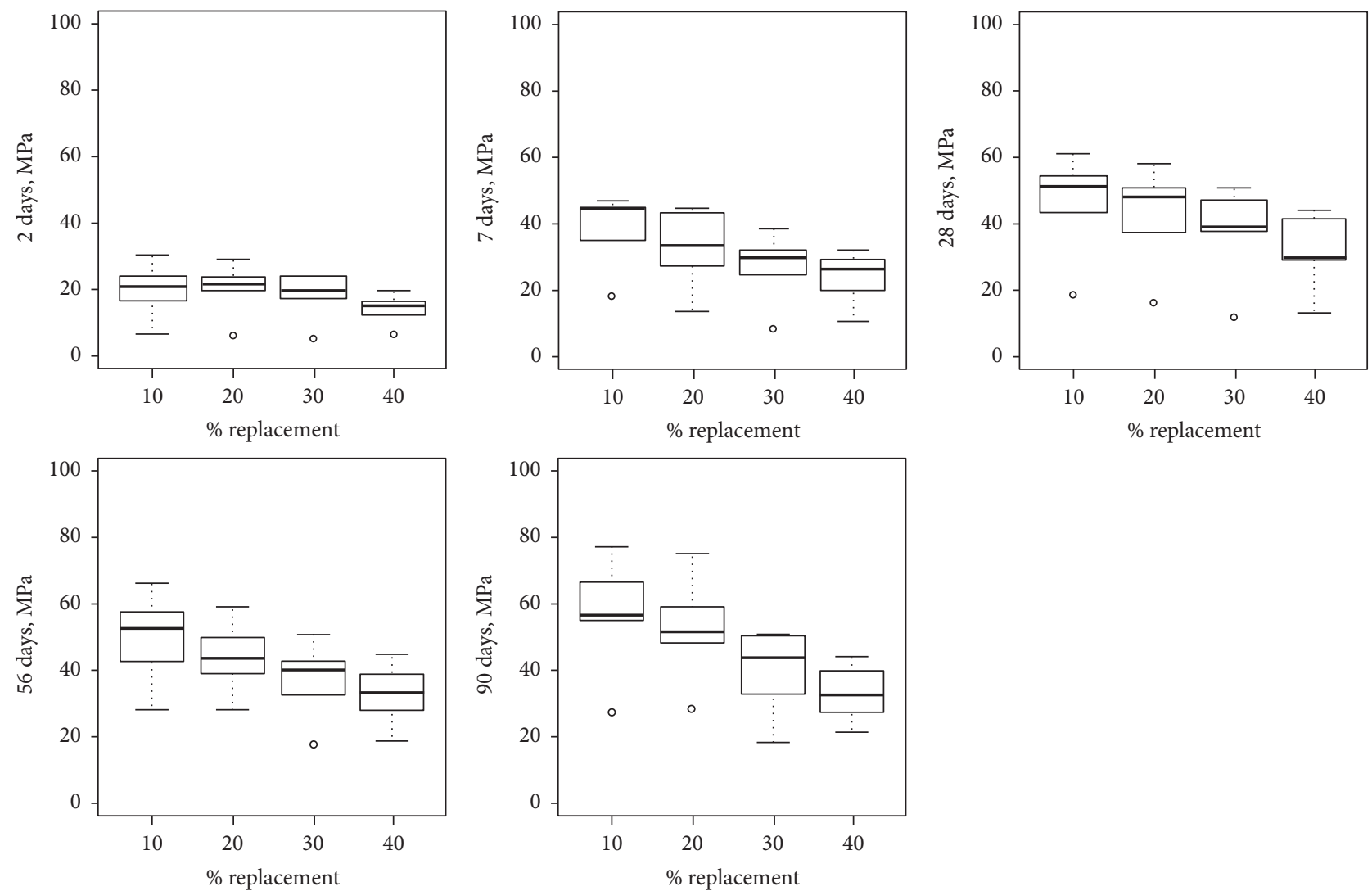

- Outliers/extreme values

(a)
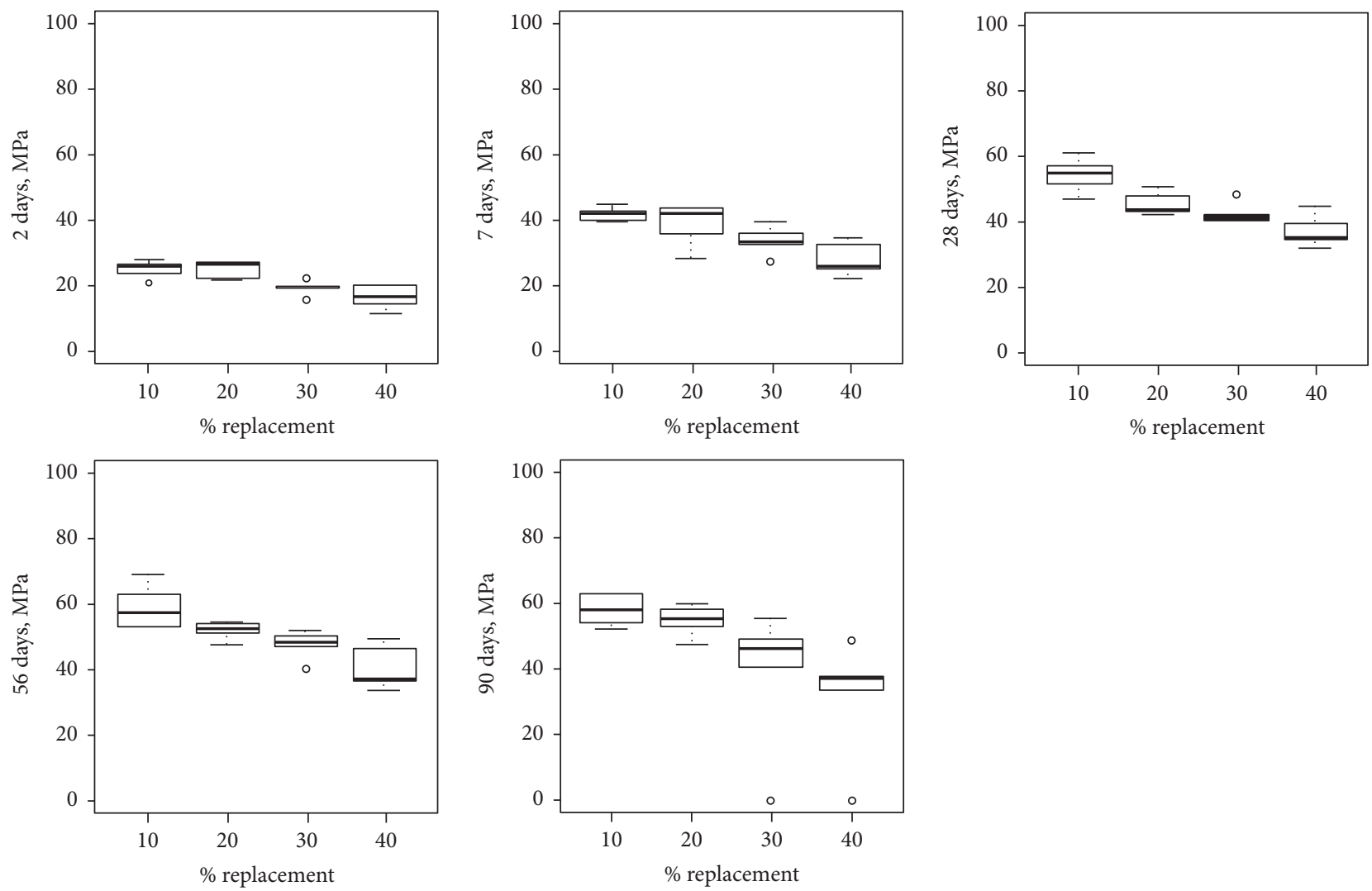

- Outliers/extreme values

(b)

Figure 8: Continued. 

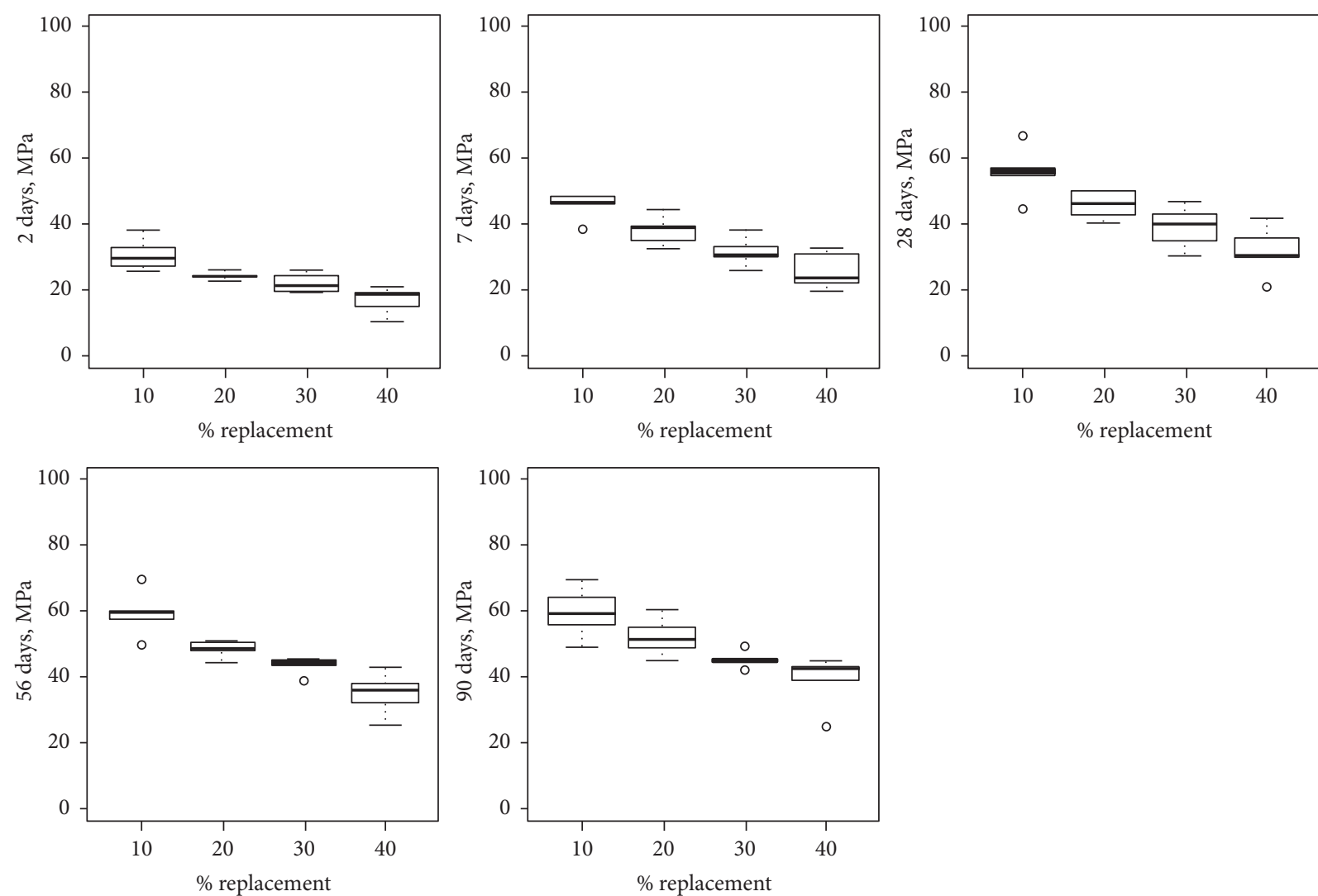

- Outliers/extreme values

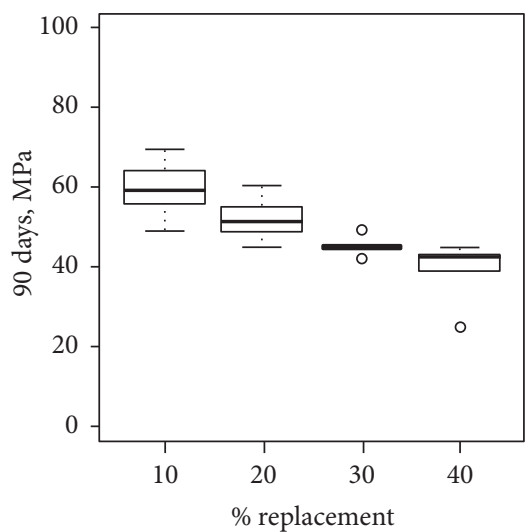

- Outliers/extreme values

(c)

FIGURE 8: Compressive strength of blended cement versus percent replacement: (a) scoria, (b) pumice, and (c) RHA.

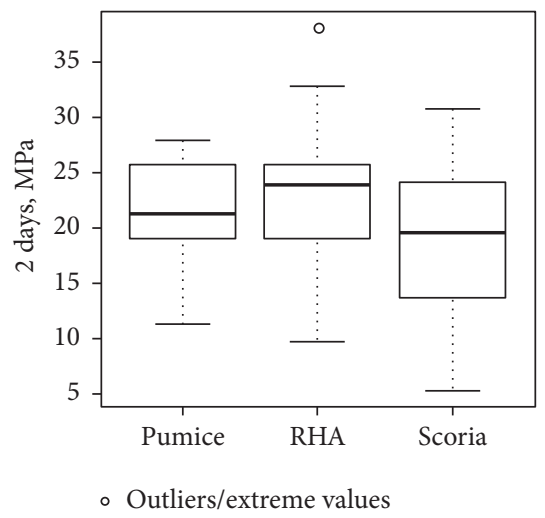

(a)

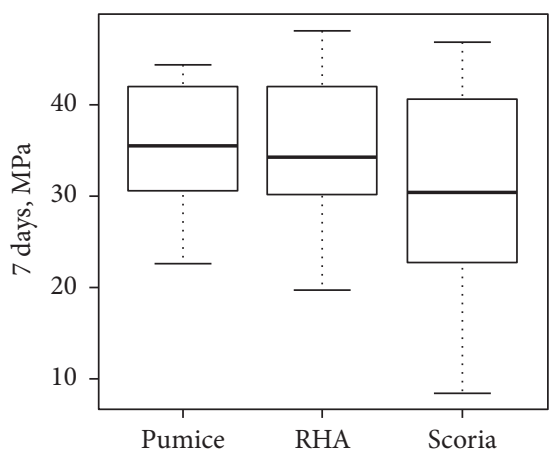

(b)

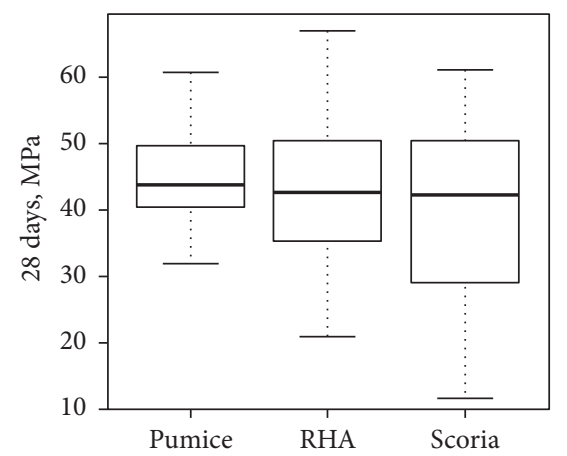

(c)

FIGURE 9: Effect of materials on compressive strength of blended cement.

which the growth rate decreased gradually with curing period as the pozzolanic reaction depleted both the $\mathrm{CH}$ and silica content.

Mean compressive strength of all samples after 2, 7, and 28 days indicates that pumice and RHA samples performed better compared to scoria samples (Figures 9(a)-9(c)). Scoria samples treated at high temperature reacted poorly due to low amorphous silica content hence contributing to low mean compressive strength. This was probably due to the decrease in the amount of reactive amorphous silica content and evolution of more nonreactive crystalline silica content with temperature. Pumice reacted slowly with $\mathrm{CH}$ from hydrating cement and gained the mean ultimate compressive strength of over $42.5 \mathrm{MPa}$ at 28 days. The mean ultimate compressive strengths at 28-day curing period for scoria, pumice, and RHA blended cement were rather similar since over 95 


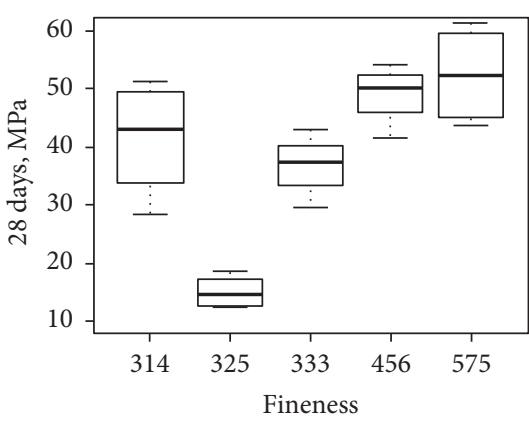

(a) Scoria

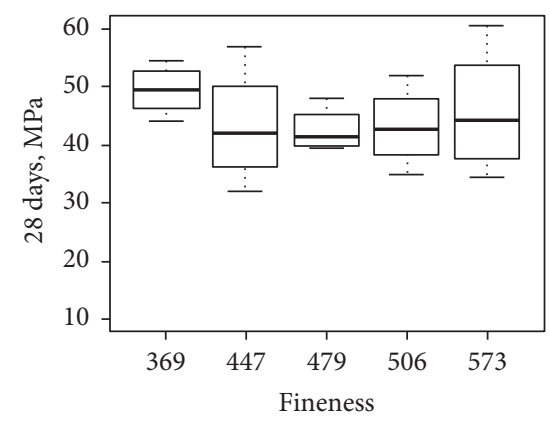

(b) Pumice

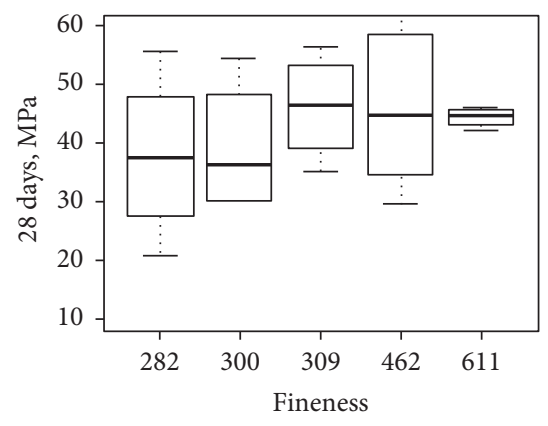

(c) Rice husk ash

FigURE 10: Effect of fineness on 28-day compressive strength.

percent of the pozzolanic reaction was over. The ultimate mean compressive strengths achieved at 28-day curing period were 44.8, 43.0, and 42.5 MPa for pumice, RHA, and scoria, respectively (Figure 9(c)). With regard to fineness, the ultimate mean strength at 28 days for scoria samples with the fineness of $575 \mathrm{~m}^{2} / \mathrm{kg}$ was $52.2 \mathrm{MPa}$ compared to 43.1 and 44.6 MPa for pumice and RHA with the fineness of 506 and $611 \mathrm{~m}^{2} / \mathrm{kg}$, respectively (Figure 10). Natural scoria achieved high compressive strength probably due to latent hydraulicity, high reactive silica content, and good parking effects.

\section{Conclusion}

Scoria, pumice, and rice husk ash materials were successfully characterized according to ASTM C 618 criteria and tested to establish their potential as SCMs. Finely milled uncalcined samples of scoria and pumices and rice husk ash calcined in uncontrolled condition with specific surface area of 575, 506 , and $611 \mathrm{~m}^{2} / \mathrm{kg}$, respectively, showed high PAI of 82 , 70.7 , and $87.8 \%$ at 7 days and $89.0,85.5$, and $88.9 \%$ at 28 days in that order. These values meet the criteria for SCMs. Pozzolanic activity indices achieved by all scoria samples at 7 days were above the specified minimum of $75 \%$. In comparison, rice husk ash achieved over $80 \%$ PAI after 7 days. Contrary, all pumice samples achieved minimum pozzolanic activity index after 28 days. Scoria and rice husk ash blended cement reached the ultimate compressive strength in 7 days while pumice blended cement achieved that in 28 days. The ultimate mean compressive strengths of $44.8,43.0$, and 42.5 MPa for pumice, RHA, and scoria, respectively, were achieved after 28-day curing period. In addition, setting time observed for all samples ranged from a minimum mean initial setting time of $80 \mathrm{~min}$ for $\mathrm{S}-\mathrm{N}$ to the maximum mean initial setting time of $154 \mathrm{~min}$ for RHA 600. Likewise, the final setting time ranged from a minimum mean final setting time of 156 min for S 900 to maximum final setting time of $190 \mathrm{~min}$ for RHA 600. Initial and final setting times for scoria, pumice, and RHA were lower compared to those of Portland pozzolana cement (PPC), which were 166 and $285 \mathrm{~min}$ as initial setting time and final setting times in that order. On the other hand, soundness and shrinkage determined for all samples had a maximum mean value of $1.5 \mathrm{~mm}$. The combination of all the above parameters demonstrated the suitability of natural scoria and pumice as SCMs.

\section{Conflicts of Interest}

The authors declare that they have no conflicts of interest.

\section{Acknowledgments}

The authors acknowledge the Nelson Mandela Institution of Science and Technology for financing this research.

\section{References}

[1] S. K. Duggal, Building Materials, New Age International (P) Limited, New Delhi, India, 3rd edition, 2008.

[2] T. Peter, B. Fatih, Y. Ezgi, and C. Halil, "Optimizing cementitious content in concrete mixtures for required performance," National Concrete Pavement Technology Center, Iowa State University, 2012.

[3] R. T. Thorstensen and P. Fidjestol, "Inconsistencies in the pozzolanic strength activity index (SAI) for silica fume according to EN and ASTM," Materials and Structures/Materiaux et Constructions, vol. 48, no. 12, pp. 3979-3990, 2015.

[4] M. P. Luxán, F. Madruga, and J. Saavedra, "Rapid evaluation of pozzolanic activity of natural products by conductivity measurement," Cement and Concrete Research, vol. 19, no. 1, pp. 63-68, 1989.

[5] W. J. McCarter and D. Tran, "Monitoring pozzolanic activity by direct activation with calcium hydroxide," Construction and Building Materials, vol. 10, no. 3, pp. 179-184, 1996.

[6] S. Wansom, S. Janjaturaphan, and S. Sinthupinyo, "Pozzolanic activity of rice husk ash: comparison of various electrical methods," Journal of Metals, Materials and Minerals, vol. 19, no. 2, p. 1, 2009.

[7] J. Paya, M. V. Borrachero, J. Monzo, E. Peris-Mora, and F. Amahjour, "Enhanced conductivity measurement techniques for evaluation of fly ash pozzolanic activity," Cement and Concrete Research, vol. 31, no. 2, pp. 41-49, 2001.

[8] M. Khandaker and A. Hossain, "Blended cement and lightweight concrete using scoria: mix design, strength, durability and heat insulation characteristics," International Journal of Physical Sciences, vol. 1, no. 1, pp. 5-16, 2006.

[9] H. A. Mboya, J. Makunza, and Y. H. Mwishwa, "Assessment of pumice blocks in comparison to cement sand blocks and burnt blocks 'the case of Mbeya city-Tanzania', Journal of Civil Engineering Research and Practice, vol. 8, no. 1, pp. 43-55, 2011.

[10] F. A. Oyawale, "Characterization of rice husk via atomic absorption spectrophotometer for optimal silica production," 
International Journal of Science and Technology, vol. 2, no. 4, pp. 210-213, 2012.

[11] G. A. Habeeb and H. B. Mahmud, "Study on properties of rice husk ash and its use as cement replacement material," Materials Research, vol. 13, no. 2, pp. 185-190, 2010.

[12] V. P. Della, I. Kühn, and D. Hotza, "Rice husk ash as an alternate source for active silica production," Materials Letters, vol. 57, no. 4, pp. 818-821, 2002.

[13] A. N. Givi, S. A. Rashid, F. N. A. Aziz, and M. A. M. Salleh, "Contribution of rice husk ash to the properties of mortar and concrete: a review," Journal of American Science, vol. 6, no. 3, pp. 157-165, 2010.

[14] BS EN 12350-1, “Test sieves-Technical requirements and testing-Part 1: test sieves of metal wire cloth,” Tech. Rep., 2000.

[15] A. Taha, A. AL-Naaymi, and A. Mohamed, "Chemical, physical and geotechnical properties comparison between scoria and pumice deposits in Dhamar-rada volcanic field-SW Yemen," Australian Journal of Basic and Applied Sciences, vol. 7, no. 11, pp. 116-124, 2013.

[16] K. N. Njau, R. J. A. Minja, and J. H. Y. Katima, "Pumice soil: potential wetland substrate for treatment of domestic wastewater 'Water Science and Technology"' IWA Publishing, vol. 48, no. 5, pp. 85-92, 2008.

[17] A. I. Ismail, O. I. El-Shafey, M. H. Amr, and M. S. El-Maghraby, "Pumice characteristics and their utilization on the synthesis of mesoporous minerals and on the removal of heavy metals," International Scholarly Research Notices, vol. 2014, pp. 1-9, 2014.

[18] SS-EN 196-2, "Method of testing cement-Part 2: chemical analysis of cement," Tech. Rep. 123867, 2013.

[19] SS-EN 196-3:2005+A1:2008 (E), Method of testing cementPart 3: determination of setting times and soundness 123867, 2015.

[20] ASTM C 618, "Standard specification for coal fly ash and raw or calcined natural pozzolan for use in concrete," Tech. Rep., 2005.

[21] SS-EN 197-1, "Cement-Part 1: composition, specification and conformity criteria for common cements," Tech. Rep. 123867, 2011.

[22] ASTM D 854, "Standard test for specific gravity of soil solids by water pycnometer," Tech. Rep., 2003.

[23] B8E1-1 Standard test method, "Standard test method specific gravity of solids \& powders," Tech. Rep. 3, 1999, http://www .yumpu.com/en/document/view/37351958/b8el-1.

[24] SS-EN 196-6:2010, "Methods of testing cement-Part 6: determination of fineness," Tech. Rep. 123867, 2010.

[25] G. Cordeiro, R. Filho, L. Tavares, E. Fairbairn, and S. Hempel, "Influence of particle size and specific surface area on the pozzolanic activity of residual rice husk ash," Cement and Concrete Composites, vol. 33, no. 5, pp. 529-534, 2011.

[26] A. M. Neville and J. J. Brooks, Concrete Technology, Pearson Education, Upper Saddle River, NJ, USA, 2nd edition, 2010.

[27] SS-EN 196-1, "Methods of testing cement-Part 1: determination of strength," Tech. Rep. 123867, 2005.

[28] L. Zongjin, Advanced Concrete Technology, John Wiley \& Sons, Hoboken, NJ, USA, 2011.

[29] I. Kett, Engineered Concrete: Mix Design and Test Methods, Taylor \& Francis Group, New York, NY, USA, 2nd edition, 2010.

[30] N. Y. Mostafa, S. A. S. El-Hemaly, E. I. Al-Wakeel, S. A. ElKorashy, and P. W. Brown, "Characterization and evaluation of the pozzolanic activity of Egyptian industrial by-products: I: Silica fume and dealuminated kaolin," Cement and Concrete Research, vol. 31, no. 3, pp. 467-474, 2001. 


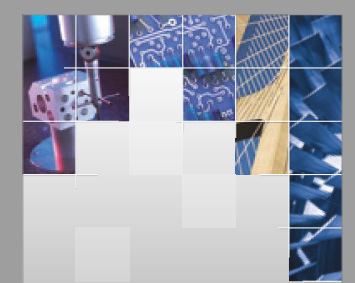

\section{Enfincering}
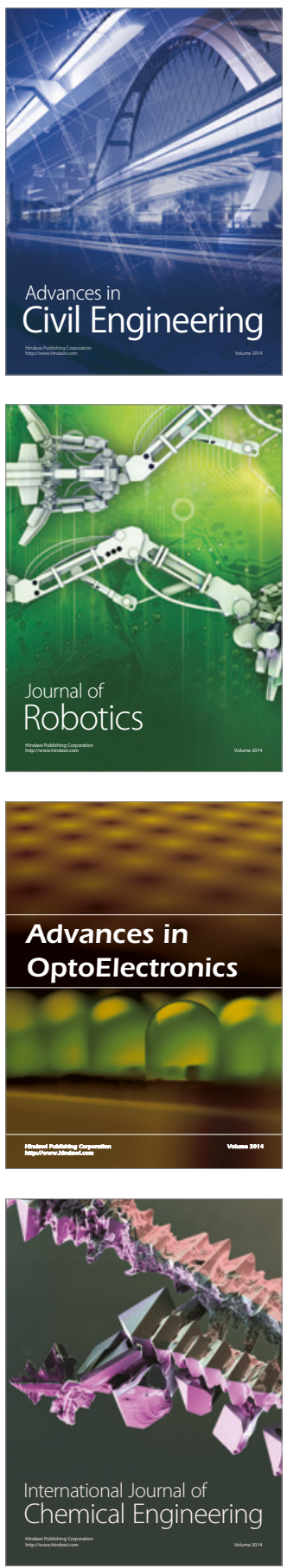

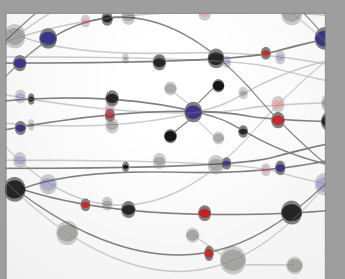

The Scientific World Journal

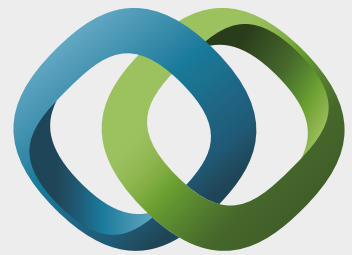

\section{Hindawi}

Submit your manuscripts at

https://www.hindawi.com
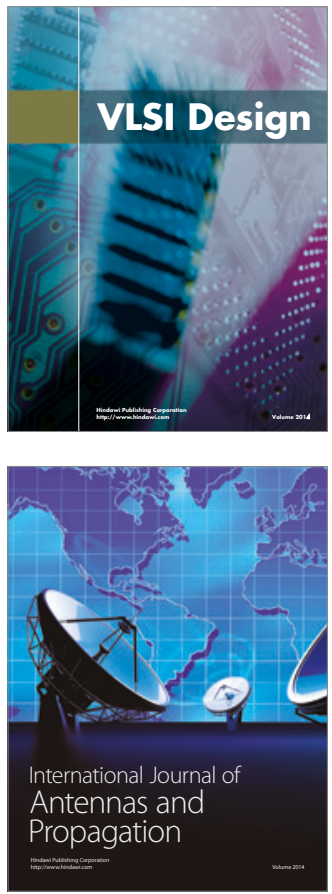

\section{Rotating}

Machinery
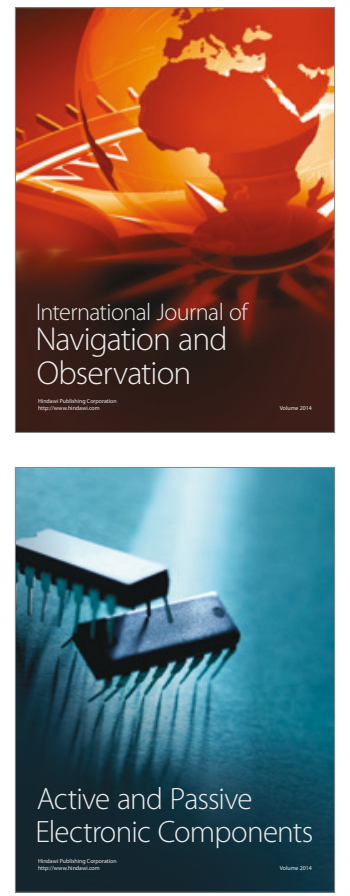
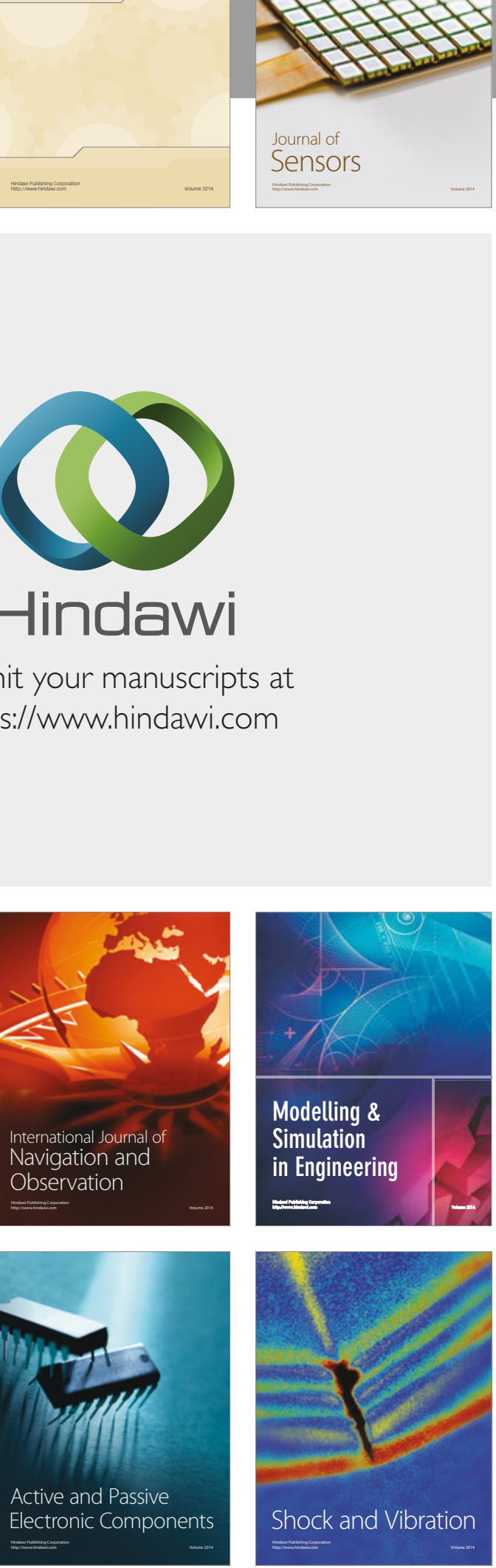
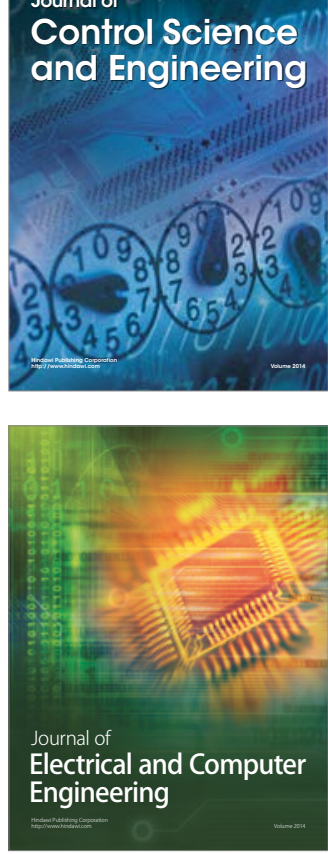

Distributed

Journal of

Control Science

and Engineering
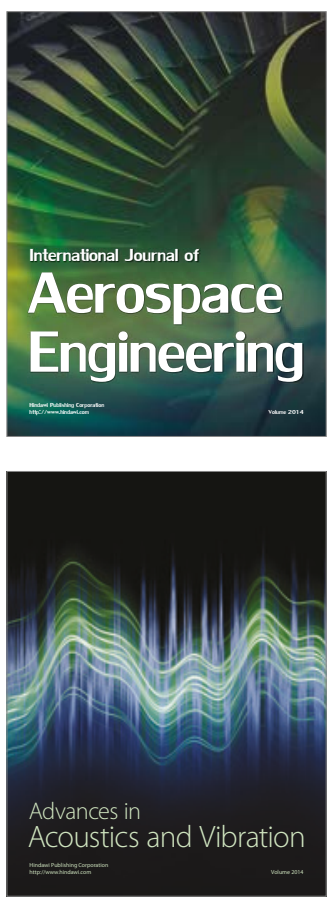

Sensor Networks 